\title{
CONTENT AND BIOLOGICAL VALUE OF PROTEIN IN GRAIN OF SPRING BARLEY ACCESSIONS
}

${ }^{1}$ Vasko N.I., ${ }^{2}$ Serik M.L., ${ }^{1}$ Kozachenko M.R., ${ }^{1}$ Naumov O.G., ${ }^{1}$ Vazhenina O.E., ${ }^{1}$ Solonechnyi P.M., ${ }^{1}$ Solonechna O.V., ${ }^{1}$ Sheliakina T.A.

${ }^{1}$ - Plant Production Institute nd. a. V.Ya. Yuriev of NAAS, Ukraine

2 - Kharkiv State University of Nutrition and Trade, Ukraine

In 2015-2017, the Plant Production Institute named after V.Ya. Yuriev of NAAS studied the dependence of protein content on growing conditions and genotype and evaluated its biological value for food production. Seventy barley lines and cultivars belonging to different varieties and originating from different eco-geographical regions were the test material. It was established that under the similar weather conditions of 2015-2017 the protein content in grain of spring barley accessions insignificantly depended on the cultivation conditions and was mainly determined by the genotype. In naked barley accessions, this parameter was significantly higher (12.05$15.46 \%)$ than that in chaffy ones (10.91-13.82\%). Among the chaffy cultivars, Rezerv was the only cultivar with the protein content significantly exceeding the average throughout the experiment (13.82\%); as to naked cultivars, 11 of 16 cultivars had protein contents higher than the average. In six-row barley, both in chaffy and in naked accessions, the protein contents were lower those in two-row barley. Cultivars Parnas and Berkut were singled out by protein digestibility as an index of biological value (69.80 and $74.20 \mathrm{mg}$ of tyrosine per $\mathrm{g}$ of protein, respectively). Berkut was created by selecting from a hybrid population Parnas / Omskiy Golozyornyy 1, therefore, Parnas is a possible source of highly digestible protein, which may be of interest in barley breeding for the production of baby and dietary foods.

Key words: spring barley, cultivar, protein content, biological value, protein digestibility, naked barley

Introduction. Barley was grown for food at least 10,000 years ago and was popular even in ancient Egypt, Greece and Rome. Over time, barley bread began inferior to wheat and rye ones, which were better to the taste. However, in some regions (Africa, Tibet, China, Korea, Japan) barley never lost its value as a food product. Recently, barley has also become of interest in other highly civilized countries - Canada, the USA, Australia, Finland, Sweden, Denmark, France and others. In 2006, the U.S. Food and Drug Administration (FDA) qualified grain as food that reduces the risk of coronary heart disease, i.e. as functional food. The very term «functional food» was born in Japan in the mid-1980s. It is a product that has therapeutic and prophylactic effects on the human body, i.e., in addition to the energy value, provides normal physiological functioning of human systems [1,2].

Analysis of publications, pose the problem. Proteins are of a great importance to the human body; they cannot be substituted by other substances, because they belong to irreplaceable essential substances. The minimum requirement of the human body for protein is $0.5 \mathrm{~g}$ per $1 \mathrm{~kg}$ of body weight, but it is the lower margin of safety for the life-sustaining activity; this will satisfy the protein requirement for $60 \%$ of the population. The optimal requirement is $0.75 \mathrm{~g}$ per $\mathrm{kg}$ of body weight; this provides an adjustment for stress situations and digestibility of proteins. The maximum requirement for proteins is $1.1 \mathrm{~g}$ per $\mathrm{kg}$ of body weight and is the upper margin for the life-sustaining activity; it satisfies the requirement for proteins of $95 \%$ of the population. For

(C) N.I. Vasko, M.L. Serik, M.R. Kozachenko, O.G. Naumov, O.E. Vazhenina, P.M. Solonechnyi, O.V. Solonechna, T.A. Sheliakina. 2018.

ISSN 1026-9959. Селекція і насінництво. 2018. Випуск 113. 
sportsmen, military servicemen and men of reproductive age, the requirement for proteins is even higher $-2.0-3.0 \mathrm{~g}$ per $\mathrm{kg}$ of body weight $[3,4]$.

In addition to protein content in foods, one should know the level of protein digestibility by the human body. This parameter determines the biological value of protein, which is due to the presence of irreplaceable amino acids, their ratio to replaceable ones and digestibility in the gastrointestinal tract. Digestibility of protein can be measured biochemically by enzymatic hydrolysis in conditions simulating those in a living organism. In this case, in vitro digestibility is determined, which comprehensively characterizes the protein under study related to the reference protein (casein) [3].

Given the paramount importance of protein to the human life, creation of high-protein cultivars of agricultural crops, including barley, one of the most valuable cereals for functional nutrition, is among the objectives of breeding. However, while breeders place a high priority on protein content, its quality is mainly studied in the context of forage for livestock husbandry. The same applies to definition of requirements for the barley grain quality as a foodstuff [5].

The protein content in grain is strongly influenced both by the growing conditions and by the genotype, and the growing condition effect is stronger. Concentration of available for plants nitrogen in soil is a factor increasing the protein content in grain. However, high protein content achieved owing to nitrogen fertilizers, is associated with an increase in replaceable amino acid (glutamic acid, proline, glutamine) amounts and with a relative decrease in amounts of irreplaceable ones (lysine, tryptophan) [1]. Negative correlation between the protein content and lysine amount in protein is typical for most barley cultivars, i.e., the higher the protein content in barley grain is, the lower its biological value is [6].

O.I. Rybalka with colleagues extensively studies the breeding of barley cultivars for functional nutrition. For example, they found that the protein content in naked accessions was always higher (17.14-21.06\%) than in chaffy ones (12.5-14.05\%), which was observed both for winter and for spring accessions. They also found that there was no significant correlation between the grain size and protein content in grain of naked cultivars, whereas a clear negative relationship was established for chaffy ones. When the digestibility of protein in barley groats from naked cultivars and in commercial groats was evaluated, solubility of protein in 50\% 1-propanol was found to be significantly higher for all the samples of barley groats than for samples of groats from wheat cultivar Selianka $(21.7 \%)$. The fraction of soluble proteins in groats from naked cultivars was also higher (33.4-45.9\%) than that in commercial groats $(29.3 \%)$. As to the growing conditions, the soluble protein content increases under dry conditions $[1,7]$.

In arid 2012, Russian researchers recorded the highest protein content in barley accessions, and in 2013 with sufficient water availability - the lowest. Cultivars Hetman, Bezynchukskyi 3, Povolzhskiy 65, Vitiaz were defined as sources of high protein content [8]. In other studies, it was found that naked two-row barley Omskiy Golozyornyy 1 exceeded naked six-row Omskiy Golozyornyy 2 and chaffy Omskiy 90 in terms of protein content $(18.82 \%, 16.19 \%$ and $16.00 \%$, respectively). In addition, the grain evenness in the multi-row cultivar was significantly lower (49.6\% vs. $74.0-76.3 \%$ in other cultivars) [9].

Researchers from the Republic of Tatarstan found that the protein content in grain of 22 barley cultivars of different eco-geographical origin was determined rather by air temperature than by varietal characteristics. The protein content was $12.21-16.69 \%$ in dry years, and in years with sufficient water availability it was reduced to $9.9-11.8 \%$ [10].

VV Glukhovtsev drew similar conclusions on the influence of weather conditions on the protein content in barley grain [11], namely - the protein content was more influenced by air temperature in June than during the grain filling phase. In addition, he found that the protein content significantly positively correlated with the contents of lysine, threonine and valine $(\mathrm{r}=0.85$ 0.99). As for the content of irreplaceable amino acids, other researchers revealed that their amounts in all protein fractions of flour were 6-12\% lower than those in barley grain [12].

Research on medical and preventive properties of barley grain is huge in the world. The amino acid composition of protein, reference intake [13], potential preventive effects of barley grain $[14,15]$, grain quality and composition, etc. are studied. [16]. 
Chinese scientists studied 10 two-row barley cultivars and found that the protein content varied greatly, depending on the sowing date and cultivar, but there was no relationship between the sowing date and cultivar. A significant difference between cultivars was noticed in the contents of hordeins B, C and D [17], which confirmed the findings of J.L. Molina-Cano et al. [18].

In a study of 30 barley accessions with various protein content, correlation were found between the protein content, molecular structure and starch granule size: the protein content significantly negatively correlated with the amylose content, and positively - with the amilopectin content. The starch granule size positively correlated with the starch content [19].

The Plant Production Institute named after V.Ya. Yuriev of NAAS consistently creates cultivars with increased protein content. In studies of 60 barley cultivars of different ecogeographical origin, the protein content in grain was found to depend on the growing conditions (including predecessor) and genotype. In waterlogged 2005, the protein content dropped to 9.449.48\% in cv. Scarlett, Aspekt and Efekt. In arid years, this parameter rose to $15.13-15.82 \%$ (Parnas, Merkurii) [20]. In 2013, which was very unfavorable for barley, the experiments were conducted on 17 cultivars in three locations with various soil and climatic conditions. It was found that cv. Zdobutok, Dokaz and Dyvohliad had the highest protein contents (15.38-15.59\%), while in cv. Parnas and Dokaz Proof this parameter was the most stable [21].

The aim and tasks of the study. Thus, studies on dependence of protein content on the growing conditions and genotype are widely conducted in breeding. However, results of these studies differ both by location and by cultivars. Therefore, such experiments do not lose relevance. As for the quality of barley protein, the number of such studies in breeding is very limited. Proceeding from the unmet need for food cultivars, it is necessary to deepen investigations of quality features of barley grain and their variability, depending on the growing conditions and genotype.

Materials and methods. The study was conducted at the Plant Production Institute named after V.Ya. Yuriev of NAAS in 2015-2017. Seventy spring barley lines and cultivars of different eco-geographical origin were taken as the test material. The cultivars and lines were grown in variety trial plots with an area of $10 \mathrm{~m}^{2}$. Significance of differences between variants was tested by analysis of variance; post hoc comparisons to generate Homogeneous groups (Fisher LSD) were performed in the STATISTICA software package. The protein content in grain was measured on an Infralume FT-10M 09495.

The protein digestibility was evaluated in the Laboratory of Medical and Biological Problems of Food Technology at the Chair of Chemistry, Microbiology and Nutrition of Kharkiv State University of Nutrition and Trade. The in vitro protein digestibility by proteolytic enzymes was assessed by O. Pokrovsky and I. Yertanov's method [22], which is based on a gradual action of a proteinase system consisting of crystalline pepsin and trypsin on proteins.

Fermentation was carried out in two 60-minute steps. Step I was pepsin fermentation at $\mathrm{pH}=2.0$; step II - trypsin fermentation at $\mathrm{pH}$ 8.0.

Samples containing $150 \mathrm{mg}$ of protein were transferred in 2 test tubes, and $15 \mathrm{~mL}$ of 0.02 $\mathrm{N} \mathrm{HCl}$ was added. $15 \mathrm{mg}$ of pepsin was placed in one test tube. The other (control) test tube had no enzyme. Samples were incubated at $38^{\circ} \mathrm{C}$ for 120 minutes with constant stirring. To determine soluble pepsinolysis products, $0.2 \mathrm{~mL}$ of digest was taken from the test tubes, and $2 \mathrm{~mL}$ of $10 \%$ trichloroacetic acid was added to the digest aliquot. The test tubes were incubated for at room temperature 20 minutes, and then they were centrifuged at $6,000 \mathrm{rpm}$ for 10 minutes. The amount of soluble pepsinolysis products was measured in supernatants by the Lowry method, and the pepsin digestibility was calculated.

For trypsinolysis, the contents of the experimental and control test tubes were neutralized with $5 \mathrm{M}$ sodium hydroxide, and $15 \mathrm{~mL}$ of $0.08 \mathrm{~N} \mathrm{NaHCO} 3$ was added. $30 \mathrm{mg}$ of trypsin was placed in the experimental test tube. Trypsinolysis was carried out at $38^{\circ} \mathrm{C}$ for 120 minutes with constant stirring. To determine the total digestibility (the amount of soluble products of protein hydrolysis by successive action of pepsin and trypsin), $0.2 \mathrm{~mL}$ of digest was taken from the test tubes, and $2 \mathrm{~mL}$ of $10 \%$ trichloroacetic acid was added. The test tubes were incubated at room temperature for 20 minutes and then centrifuged at $6,000 \mathrm{rpm}$ for 10 minutes. The amount of sol- 
uble hydrolysis products was evaluated by the Lowry method, and the pepsin and total digestibilities of protein were calculated.

Results and discussion. The weather conditions during the study years little differed; therefore, the protein content in grain of the accessions was similar across the years. The HTC over the study years exceeded 1.5. There was a severe drought associated with high temperatures during the grain filling phase in 2017, nevertheless, the negative effect of such weather conditions was compensated by waterlogging during the tillering and earing phases, which contributed to the high productive tillering capacity.

To determine the genotype effect on the protein content, all the accessions were grouped according to their features, namely: chaffy with wild-type starch (about 20\% amylose, $80 \%$ amylopectin), chaffy with waxy starch $(100 \%$ amylopectin), naked with wild-type starch and naked with waxy starch.

The protein content was significantly higher in naked accessions than in chaffy ones (14.08-14.30\% vs. 12.11-12.37\%, respectively) (Tables 1 and 2).

Table 1.

Protein content in chaffy spring barley accessions with wild-type and waxy starch

\begin{tabular}{|c|c|c|c|c|c|}
\hline \multirow{2}{*}{$\begin{array}{l}\text { Accession } \\
\text { /Line }\end{array}$} & \multirow{2}{*}{ Cultivar/ Variety } & \multicolumn{3}{|c|}{ Year } & \multirow{2}{*}{ Average } \\
\hline & & 2017 & 2016 & 2015 & \\
\hline \multirow[t]{3}{*}{1} & 2 & 3 & 4 & 5 & 6 \\
\hline & Vzirets submedicum & $11.48 * *$ & 12.97 & 13.20 & 12.55 \\
\hline & Komandor nutans & 13.06 & 12.45 & 12.00 & 12.50 \\
\hline $08-1385$ & Balzam nutans & 12.56 & 11.99 & 13.24 & 12.60 \\
\hline $08-2455$ & Grin nutans & 12.34 & $10.59 * *$ & 12.94 & 11.96 \\
\hline $12-215$ & Stymul nutans & 12.65 & 12.34 & 12.87 & 12.62 \\
\hline $12-523$ & Lider nutans & 13.68 & 12.03 & $11.67 * *$ & 12.46 \\
\hline \multirow[t]{3}{*}{$09-2162$} & rikotense & $10.76^{* *}$ & 12.26 & 12.01 & $11.68 * *$ \\
\hline & Vakula rikotense & $10.68 * *$ & 12.49 & 12.04 & $11.74 * *$ \\
\hline & Khadar nutans & $11.60 * *$ & 12.09 & $11.77 * *$ & $11.82 * *$ \\
\hline \multirow[t]{5}{*}{$04-476$} & Modern inerme & $11.65 * *$ & 12.79 & $11.72 * *$ & 12.05 \\
\hline & Cozvan nutans & 11.86 & $11.60 * *$ & $11.57 * *$ & $11.68 * *$ \\
\hline & Etyket submedicum & $11.25 * *$ & 12.69 & $13.90 *$ & 12.61 \\
\hline & Inkliuzyv nutans & 12.85 & 12.78 & 12.71 & 12.78 \\
\hline & Parnas nutans & 12.32 & 12.01 & 11.86 & 12.06 \\
\hline $99-103 / 96-18$ & Dokaz nutans & 12.32 & $11.69 * *$ & 13.07 & 12.36 \\
\hline \multirow[t]{2}{*}{ 03-18/99-9 } & Alegro nutans & 12.32 & 12.46 & 12.98 & 12.59 \\
\hline & Agrariy nutans & 12.01 & 12.89 & 13.63 & 12.84 \\
\hline $08-73$ & Maliovnychyi nutans & 12.47 & 12.76 & 13.71 & 12.98 \\
\hline $06-658 a$ & Khors nutans & 12.53 & 12.76 & 12.90 & 12.73 \\
\hline $08-182$ & Podyv nutans & 12.37 & 12.79 & 13.14 & 12.77 \\
\hline \multirow[t]{7}{*}{$09-837$} & Avgur nutans & 12.19 & 12.34 & 12.35 & 12.29 \\
\hline & Rezerv nutans & 13.37 & 13.56 & $14.52 *$ & $13.82 *$ \\
\hline & Ranger nutans & $11.19 * *$ & $10.99 * *$ & $11.45 * *$ & $11.21 * *$ \\
\hline & Tolar nutans & 12.96 & 13.04 & 13.19 & 13.06 \\
\hline & Getman nutans & $11.49 * *$ & 13.13 & 12.01 & 12.21 \\
\hline & Sviatogor nutans & $11.28 * *$ & 13.38 & 13.26 & 12.64 \\
\hline & Xanadu nutans & 12.25 & 12.60 & 12.35 & 12.40 \\
\hline
\end{tabular}


Continue Table 1.

\begin{tabular}{|c|c|c|c|c|c|}
\hline 1 & 2 & 3 & 4 & 5 & 6 \\
\hline & Germes nutans & 12.51 & $14.15^{*}$ & 12.40 & 13.02 \\
\hline & Donetskyi 15 & 13.27 & 11.90 & 12.66 & 12.61 \\
\hline & Donetskyi 14 & 12.61 & $14.18^{*}$ & 12.86 & 13.22 \\
\hline & Donetskyi 12 medicum & 12.47 & 13.43 & 12.07 & 12.66 \\
\hline & Brovar nutans & $11.59 * *$ & 13.54 & 12.66 & 12.60 \\
\hline & Ladny nutans & $10.77 * *$ & 12.30 & $11.61 * *$ & $11.56^{* *}$ \\
\hline & Ilek 9nutans & $11.30 * *$ & $14.00^{*}$ & 12.35 & 12.55 \\
\hline & Sofiara nutans & 11.91 & 13.24 & $11.76 * *$ & 12.30 \\
\hline & Shakira nutans & 12.11 & 12.85 & 12.94 & 12.63 \\
\hline & Kangoo nutans & 12.31 & 12.90 & $10.81 * *$ & 12.01 \\
\hline & Sebastian nutans & $11.34 * *$ & 12.04 & $10.78 * *$ & $11.39 * *$ \\
\hline & Novosadsky 294 nutans & 12.27 & $14.40^{*}$ & 12.87 & 13.18 \\
\hline \multirow[t]{8}{*}{$13-652$} & inerme & $11.41 * *$ & $14.12 *$ & 12.40 & 12.64 \\
\hline & Pasadena nutans & $11.57 * *$ & $14.39^{*}$ & 12.06 & 12.67 \\
\hline & Ratnik nutans & $11.63 * *$ & 13.49 & 13.31 & 12.81 \\
\hline & Abalak nutans & $11.14 * *$ & $11.77 * *$ & 13.64 & 12.18 \\
\hline & Vyklyk nutans & 12.10 & $13.89 *$ & 12.00 & 12.66 \\
\hline & Zvershennia nutans & 12.56 & $13.76^{*}$ & 13.40 & 13.24 \\
\hline & Badioryi submedicum & $11.20 * *$ & $11.75 * *$ & 12.40 & $11.78 * *$ \\
\hline & Dzherelo nutans & 12.87 & 13.60 & 13.25 & 13.24 \\
\hline \multicolumn{2}{|c|}{ Mean (chaffy with wild-type starch) } & 12.04 & 12.52 & 12.56 & 12.37 \\
\hline \multirow{2}{*}{\multicolumn{2}{|c|}{$\begin{array}{l}\max \\
\min \end{array}$}} & 13.68 & 14.40 & 14.52 & 13.82 \\
\hline & & 10.68 & 10.59 & 10.78 & 11.21 \\
\hline \multicolumn{2}{|l|}{$06-652$} & $11.40 * *$ & 12.43 & $11.19 * *$ & $11.67 * *$ \\
\hline \multicolumn{2}{|l|}{$09-791 \mathrm{a}$} & 13.10 & $14.02 *$ & 13.47 & 13.53 \\
\hline \multicolumn{2}{|l|}{$12-954$} & 13.47 & 13.05 & 12.93 & 13.15 \\
\hline \multicolumn{2}{|l|}{$12-1014$} & $10.33 * *$ & $11.05 * *$ & $11.68 * *$ & $11.02 * *$ \\
\hline \multicolumn{2}{|l|}{$12-833$} & $11.34 * *$ & 12.73 & $11.27 * *$ & $11.78 * *$ \\
\hline $12-473$ & Shedevr pallidum & $10.45 * *$ & 11.96 & $10.33 * *$ & $10.91 * *$ \\
\hline \multirow[t]{2}{*}{$12-476$} & Amil pallidum & $11.09 * *$ & 12.70 & $14.31 *$ & 12.70 \\
\hline & $\mathrm{LSD}_{05}$ & & & & 0.95 \\
\hline \multicolumn{2}{|c|}{ Mean (chaffy with waxy starch) } & 11.60 & 12.56 & 12.17 & 12.11 \\
\hline \multicolumn{2}{|r|}{$\max$} & 13.47 & 14.02 & 14.31 & 13.53 \\
\hline \multicolumn{2}{|r|}{$\min$} & 10.33 & 11.05 & 10.33 & 10.91 \\
\hline
\end{tabular}

$*$ - the protein content is significantly higher than the average $(12.81 \%)$,

$* *$ - the protein content is significantly lower than the average, $p<0,05$.

There were significant differences in the protein content depending on the genotype. For example, the protein content of chaffy cv. Rezerv was significantly higher $(13.82 \%)$ than the average across the chaffy accessions (12.81\%). This cultivar is characterized by high drought tolerance, therefore the increased protein content is inherent to it, like to all cultivars belonging to the steppe ecotype. This parameter was also high in cv. Zvershennia, Dzherelo (13.24\%), Donetskyi 14 (13.22\%), and Novosadsky 294 (13.18\%) (see Table 1).

A number of cultivars and lines had a low protein content, significantly lower than the average: Ranger (11.21\%), Sebastian (11.39\%), Ladny (11.56\%), 09-2162, Cozvan (11.68\%), Vakula (11.74\%), Badioryi (11.78\%), Khadar (11.82\%). These accessions belong to the Western European type, they are low-protein and suitable for brewing. Among the chaffy waxy acces- 
sions, the following cultivars and lines had a low-protein content: Shedevr (10.91\%), 12-1014 (11.02\%), 06-652 (11.67\%), 12-833 (11.78\%) (see Table 1).

Naked accessions were characterized by higher protein content compared to chaffy ones. For example, the protein content in cv. Hatunok (15.46\%), Merlin (15.23\%), Kozatskyi (15.16\%), Alamo (14.93\% ), Akhilles (14.61\%), Golozyornyy 1 (14.56\%), Mebere (14.54\%), Millhouse, Maiskiy (14.29\%) significantly exceeded the average (see Table 2). None of the naked accessions had protein content significantly lower than the average.

Table 2 .

Protein content in naked spring barley accessions with wild-type and waxy starch

\begin{tabular}{|c|c|c|c|c|c|}
\hline \multirow{2}{*}{ Variety } & \multirow{2}{*}{ Line/Cultivar } & \multicolumn{3}{|c|}{ Year } & \multirow{2}{*}{ Average } \\
\hline & & 2017 & 2016 & 2015 & \\
\hline nudum & $13-301$ & 13.44 & $13.90^{*}$ & $11.24 * *$ & 12.86 \\
\hline nudum & Berkut & 13.69 & $14.16^{*}$ & 12.76 & 13.54 \\
\hline nudum & Millhouse & $15.99 *$ & $14.47^{*}$ & 12.40 & $14.29 *$ \\
\hline nudum & Golozyornyy 1 & $14.68^{*}$ & $14.06^{*}$ & $14.94 *$ & $14.56^{*}$ \\
\hline nudum & Richard & $14.50 *$ & 12.72 & 12.88 & 13.37 \\
\hline coeleste & Buck & $11.66^{* *}$ & 12.03 & 12.46 & 12.05 \\
\hline nudum & Akhilles & $14.15^{*}$ & $15.22 *$ & $14.45^{*}$ & $14.61 *$ \\
\hline nudum & Maiskiy & $14.29 *$ & $14.20^{*}$ & $14.37 *$ & $14.29 *$ \\
\hline nudum & Oskar & 13.47 & 13.68 & $14.60^{*}$ & $13.92 *$ \\
\hline nudum & Hatunok & $15.14^{*}$ & $15.38^{*}$ & $15.85^{*}$ & $15.46^{*}$ \\
\hline nudum & Merlin & $15.73^{*}$ & $14.36^{*}$ & $15.60^{*}$ & $15.23^{*}$ \\
\hline nudum & Kozatskyi & $15.06^{*}$ & $15.19^{*}$ & $15.23 *$ & $15.16^{*}$ \\
\hline nudum & Omskiy golozyornyy 1 & $13.72 *$ & 13.24 & $14.52 *$ & $13.83 *$ \\
\hline \multicolumn{2}{|c|}{ Mean (naked with wild-type starch) } & 14.26 & 14.04 & 13.93 & 14.08 \\
\hline \multicolumn{2}{|r|}{$\max$} & 15.14 & 15.38 & 15.85 & 15.46 \\
\hline \multicolumn{2}{|r|}{$\min$} & 11.66 & 12.03 & 11.24 & 12.05 \\
\hline nudum & Mebere & $14.38^{*}$ & $14.47^{*}$ & $14.76^{*}$ & $14.54^{*}$ \\
\hline nudum & Candle & $13.96^{*}$ & 12.59 & $13.74 *$ & 13.43 \\
\hline nudum & Alamo & $16.74 *$ & $13.76^{*}$ & $14.30^{*}$ & $14.93^{*}$ \\
\hline \multicolumn{2}{|r|}{$\mathrm{LSD}_{05}$} & & & & 0.95 \\
\hline \multicolumn{2}{|c|}{ Mean (naked with waxy starch) } & 15.03 & 13.61 & 14.27 & 14.30 \\
\hline \multicolumn{2}{|r|}{$\max$} & 16.74 & 14.36 & 15.60 & 14.93 \\
\hline \multicolumn{2}{|r|}{$\min$} & 13.96 & 12.59 & 13.74 & 13.43 \\
\hline
\end{tabular}

* - the protein content is significantly higher than the average $(12.81 \%)$,

** - the protein content is significantly lower than the average, $p<0,05$.

Six-row accessions generally had significantly lower protein contents compared to tworow ones in all the groups. Thus, with the average across the chaffy accessions of $12.11-12.37 \%$, the protein content in six-row accessions was 10.91-11.74\%. The exception was cultivar Amil with a protein content of $12.70 \%$ (see Table 1), but even this level was low in comparison with other chaffy accessions. Similarly, six-row naked cultivar Buck had a significantly lower protein content $(12.05 \%)$ than the average across the naked accessions.

High protein content is a very important feature for food barley breeding and food production. Nevertheless, in addition to protein content, its biological value should be taken into account. Determination of the digestibility of plant protein by the human digestive system is a method for evaluating the biological value of protein.

Analysis of the digestibility of protein by proteolytic enzymes showed that the protein of cv. Parnas and Berkut (naked) was highly digestible (69.80-7420 mg/g) (Table 3). The trypsinolysis data are especially conspicuous (54.60-48.70 mg/g). 
In vitro digestibility of protein of spring barley accessions by GI enzymes, 2017

\begin{tabular}{cccc}
\hline & \multicolumn{3}{c}{$\begin{array}{c}\text { Amount of soluble products of protein hydrolysis, } \\
\text { mg of tyrosine per g of protein }\end{array}$} \\
\cline { 2 - 4 } Accession & Pepsinolysis & Trypsinolysis & $\begin{array}{c}\text { Pepsinolysis }+ \\
\text { Trypsinolysis }\end{array}$ \\
\hline Wheat Doskonala & 17.05 & 36.85 & 53.90 \\
Amil & 9.15 & 34.65 & 43.80 \\
13-301 & 14.30 & 36.30 & 50.60 \\
Parnas & 15.20 & 54.60 & 69.80 \\
Berkut (Parnas / Omskiy & 25.50 & 48.70 & 74.20 \\
golozyornyy 1) & 11.55 & 25.80 & 37.35 \\
Vzirets & 14.05 & 38.75 & 52.80 \\
Akhilles & 7.70 & 39.60 & 47.30 \\
Alamo & 14.30 & 41.80 & 56.10 \\
\hline Omskiy golozyornyy 1 & 5 & & \\
\hline Sign
\end{tabular}

Significance level: $\mathrm{n}=5, \mathrm{P} \geq 0.95, \leq 5$

Cultivar Berkut was created by selecting from hybrid population Parnas / Omskiy Golozyornyy 1 . Thus, Parnas can be a source of highly digestible protein. This is important for the breeding of cultivars for dietic and baby food production.

Conclusions. Thus, it was established that under similar weather conditions the protein content in grain of spring barley accessions was mainly determined by the genotype. In naked barley accessions, this parameter was significantly higher (12.05-15.46\%) than in chaffy ones (10.91-13.82\%). Of the chaffy accessions, Rezerv was the only cultivar with the protein content (12.81\%) significantly exceeding the average throughout the experiment (13.82\%). Eleven of 16 naked accessions had the protein contents significantly exceeding the average.

Cultivars Parnas and Berkut were noticeable for to the biological value of protein $(69.80$ and $74.20 \mathrm{mg}$ of tyrosine per g of protein, respectively). Since cv. Berkut was created by selecting from a hybrid population Parnas / Omskiy Golozyornyy 1, Parnas is can be a source of highly digestible protein. This is important for the breeding of barley cultivars for the production of baby and dietic foods.

\section{References}

1. Rybalka OI, Morgun BV, Polishchuk SS. Barley as a product of functional nutrition. Kyiv: Logos, 2016. P. 172, 517-574/

2. Newman R, Newman C. Barley for food and health. Science, technology and products. John Willley \& Sons. Hoboken, New Jersey, 2008. 245 p.

3. Zubar NM. Fundamentals of nutrition physiology and hygiene. Kyiv: Tsentr uchbovoyi literatury, 2010. P. 70-79.

4. Kotenko GS, Kotenko RM. Food commodity science. Ivano-Frankivsk, 2012. P. 14-15.

5. Ulrih SE. Barley in food production / translated by N. Ulyanitskaya. Zerno. 2010; 12. URL:www.zerno-ua/com.

6. Newman C, Newman R. Hulless barley for food and feed. In: Specialty grains for food and feed. E Abdel-Aal, P Wood, editors. American Association of General Chemists. St. Paul., MN, 2005. P. 167-202.

7. Rybalka OI, Polishchuk SS, Kirdoglo YeK, Morgun BV. Genetic and breeding criteria for creation of food naked barley cultivars. Fiziologia I biokhimia kulturnykh rasteniy. 2013; 45(3): 187-205.

8. Yusova OA, Nikolaiev OA. Evaluation of new promising sources of increased barley performance and grain quality in the southern forest-steppe of Western Siberia. Vestnik Krasnoyarskogo gosudarstvennogo agrarnogo universiteta. 2016; 12: 26-32. 
9. Kolmakov $\mathrm{YuV}$, Aniskov NI. Evaluation of and requirements for the grain quality of groats naked barley. Agrarnyi vestnik Yugo-Vostoka. 2009; 3: 21-23.

10. Blokhin VI, Lanochkina MA, Vildanova GV, Ganiyeva IS, Shaytanov OL, Talanov IP. Protein formation in grain of barley cultivars grown in Tatarstan. Vestnik Kazanskogo GAU. 2016; 1(39): 10-15. DOI: 10.12737/19300.

11. Glukhovtsev VV, Drovalieva NV. Qualitative composition of protein in spring barley grain the Middle Volga region. Zernovoie khoziaystvo Rossii. 2012; 2(20). URL: www.zhros.ru/num23(5).../st07_02_2012_20_Gluxovcev.ht...

12. Linko R, Lapveteläinen A, Laakso P, Kallio H. Protein composition of a high-protein barley flour and barley grain. Cereal Chem. 1989; 66(6): 478-482.

13. Fitzpatrick K, Adolphe J. Barley - a healthy protein source. Gobarley. 2015. URL: www.gobarley.com/...content/Gobarley-Healthy-Protein-Source.

14. Ware M. What are the health benefits of barley? Medical News Today. 2018. URL: www.medicalnewstoday.com/articles/295268.php.

15. Shewry PR. Improving the protein content and quality of temperature cereals: wheat, barley and rye. Impacts agriculture on human health and nutrition. 2004. URL: www.eols.net/sample-charters/c10/E5-21-04-04.pdf.

16. Malik AH. Nutrient uptake, transport and translocation in cereals: influences of environment and farming conditions. Swedish Univ. of Agricultural Sciences.Alnarp. 2009. P. 17-22.

17. Jung-cang Qi, Jin-xin Chen, Jun-mei Wang, Fei-bo Wu, Lian-pu Cao, Guo-ping Zhang. Protein and hordein fraction content in barley seeds as affected by sowing date and their relations to malting quality. J. Zhejiang Univ. Sci. B. 2005; 6(11): 1069-1075. DOI: 10.1631/jzus.2005.B1069.

18. Molina-Cano JL, Polo JP, Romera E, Araus JL, Zarco J, Swanta JS. Relationships between barley hordeins and malting quality in a mutant of cv. Triumph. I. Genotype by environment interaction of hordein content. J. Sereal Sci. 2001; 34: 285-294.

19. Yu W, Tan X, Zou W, Hu Zh, Fox GP, Gidley MJ, Gilbert RG. Relationships between protein content, starch molecular structure and grain size in barley. Carbohydrate Polymers. 2017; 155: 271-279. DOI: 10.1016/j.carbpol.2016.08.078.

20. Kozachenko MR, Vazhehina OE. Breeding-genetic peculiarities of performance and brewing quality of spring barley cultivars. In: Genetic patterns of spring barley breeding. MR Kozachenko, editor. Kharkiv, 2016. P. 94-130.

21. Solonechnyi PM, Kozachenko MR, Vasko NI, Naumov OG, Dmytrenko PP, Kovalenko OL. Adaptive features of spring barley cultivars in terms of the yield capacity and protein content in grain. Visnyk TsNZ APV Kharkivskoyi oblasti. 2014; 16: 225-229.

22. Pokrovsky AA, Yertanov ID. In vitro digestibility of food proteins by proteolytic enzym. Voprosy pitaniya. $1965 ; 1: 38-44$.

\section{ВМІСТ ТА БІОЛОГІЧНА ЦІННІСТЬ БІЛКА У ЗЕРНІ ЗРАЗКІВ ЯЧМЕНЮ ЯРОГО}

${ }^{1}$ Васько Н.І., ${ }^{2}$ Серік М.Л., ${ }^{1}$ Козаченко М.Р., ${ }^{1}$ Наумов О.Г., ${ }^{1}$ Важеніна О.С.,

${ }^{1}$ Солонечний П.М., ${ }^{1}$ Солонечна О.В., ${ }^{1}$ Шелякіна Т.А.

1 - Інститут рослинництва ім. В.Я. Юр`єва НААН

2 - Державний університет харчування та торгівлі

Мета і задачі дослідження. Метою дослідження було виділення генотипів 3 високим вмістом білка як матеріалу для селекційних досліджень із створення сортів ячменю ярого харчового напряму використання. Для цього було досліджено мінливість вмісту білка у різних зразків ячменю - плівчастих і голозерних із звичайним та шаху крохмалем. 3 метою визначення цінності білка було визначено його перетравлюваність.

Матеріали і методи. Дослідження проводили в Інституті рослинництва ім. В.Я. Юр‘єва НААН у 2015-2017 pp. Вихідним матеріалом були 70 ліній та сортів ячменю ярого різного еколого-географічного походження та різновидів. Сорти та лінії вирощували в дослідах сортовипробування, площа ділянки $10 \mathrm{~m}^{2}$. Істотність відмінностей між варіанта- 
ми визначали за допомогою дисперсійного аналізу ANOVA, апостеріорне порівняння за Homogenous groups (Fisher LSD) по програмі STATISTICA 10. Вміст білка в зерні визначали на ИнфраЛЮМ ФТ-10М 09495.

Перетравлюваність білка визначали в лабораторії медико-біологічних проблем технології харчових продуктів на кафедрі хімії, мікробіології та харчування Державного університету харчування та торгівлі на основі методики О. Покровского і И. Эртанова.

Обговорення результатів. Установлено, що в погодних умовах 2015-2017 років вміст білка у зерні зразків ячменю ярого в залежності від умов вирощування істотно не змінюється і визначається, в основному, генотипом. У зразків голозерного ячменю цей показник істотно вищий (12,05-15,46 \%), ніж у плівчастих (10,91-13,82 \%). Серед плівчастих сортів істотно вищий за середнє значення по досліду вміст білка був лише у сорту Резерв $(13,82 \%)$, а у голозерних - у 11 сортів з 16 вивчених. У шестирядних ячменів, як плівчастих, так і голозерного, вміст білка нижчий, ніж у двохрядних. За перетравлюваністю білка як показником біологічної цінності виділено сорти Парнас і Беркут $(69,80$ i 74,20 мг тирозину на 1 г білка відповідно). Сорт Беркут створено добором з гібридної популяції Парнас / Омский голозерный 1, тому Парнас є можливим джерелом білка 3 високою перетравлюваністю, що представляє інтерес для селекції сортів ячменю для виробництва продукції дитячого та дієтичного харчування.

Висновки. Таким чином, у результаті трирічних досліджень виділено зразки із стабільно високим вмістом білка. Це голозерні сорти вітчизняної селекції Гатунок $(15,46$ \%), Козацький $(15,16 \%)$, Ахіллес (14,61 \%) та закордонної Merlin (15,23\%), Alamo (14,93 \%), Mebere (14,54 \%), Millhouse (14,29\%), Голозерный 1 (14,56 \%), Майский $(14,29 \%)$.

Установлено, що характерним $є$ більш низький вміст білка у шестирядних зразків у порівнянні з двохрядними у всіх виділених групах.

За показником біологічної цінності білка виділено сорти Парнас і Беркут $(69,80$ і 74,20 мг тирозину на 1 г білка відповідно). Сорт Парнас $є$ можливим джерелом білка з високою перетравлюваністю. Це має значення для селекції сортів ячменю для виробництва продукції дитячого і дієтичного харчування.

Ключові слова: ячмінь ярий, сорт, вміст білка, біологічна цінність, перетравлюваність білка, голозерний ячмінь

\section{СОДЕРЖАНИЕ И БИОЛОГИЧЕСКАЯ ЦЕННОСТЬ БЕЛКА В ЗЕРНЕ ОБРАЗЦОВ ЯЧМЕНЯ ЯРОВОГО}

${ }^{1}$ Васько Н.И., ${ }^{2}$ Серик М.Л., ${ }^{1}$ Козаченко М.Р., ${ }^{1}$ Наумов А.Г., ${ }^{1}$ Важенина О.Е.,

${ }^{1}$ Солонечный П.Н., ${ }^{1}$ Солонечная О.В., ${ }^{1}$ Шелякина Т.А.

1 - Институт растениеводства им. В.Я. Юрьева НААН, Украина

2 - Государственный университет питания и торговли

Цель и задачи исследования. Целью исследования было выделение генотипов с высоким содержанием белка в зерне как материала для селекционных исследований по созданию сортов ячменя ярового пищевого направления использования. Для этого было исследовано изменчивость содержания белка у различных образцов ячменя - пленчатых и голозерных с обычным и шаху крахмалом. С целью определения ценности белка была определена его переваримость.

Материалы и методы. Исследования проводили в Институте растениеводства им. В.Я. Юрьева НААН в 2015-2017 гг. Исходным материалом были 70 линий и сортов ячменя ярового различного эколого-географического происхождения. Сорта и линии выращивали в опытах сортоиспытания, площадь делянки $10 \mathrm{~m}^{2}$. Существенность различий между вариантами определяли с помощью дисперсионного анализа, апостериорное сравнение - по Homogenous groups (Fisher LSD) по программе STATISTICA 10. Содержание белка в зерне определяли на ИнфраЛЮМ ФТ-10М 09495. 
Переваримость белка определяли в лаборатории медико-биологических проблем технологии пищевых продуктов на кафедре химии, микробиологии и питания Государственного университета питания и торговли на основе методики О. Покровского и И. Эртанова.

Обсуждение результатов. Установлено, что в условиях 2015-2017 гг. содержание белка в зерне образцов ячменя ярового в зависимости от условий выращивания существенно не изменяется и определяется, в основном, генотипом. У образцов голозерного ячменя этот показатель существенно выше (12,05-15,46 \%), чем у пленчатых (10,91-13,82 \%). Среди пленчатых сортов содержание белка существенно выше среднего по опыту было только у сорта Резерв (13,82 \%), а у голозерных - у 11 сортов из 16 изученных. У шестирядных ячменей, как пленчатых, так и голозерных, содержание белка ниже, чем у двурядных. По переваримости белка как показателю биологической ценности выделены сорта Парнас и Беркут (69,80 и 74,20 мг тирозина на 1 г белка соответственно). Сорт Беркут создан отбором из гибридной популяции Парнас / Омский голозерный 1, поэтому Парнас является возможным источником белка с высокой переваримостью, представляющим интерес для селекции сортов ячменя для производства продукции детского и диетического питания.

Выводы. Таким образом, в результате трехлетних исследований выделены образцы со стабильно высоким содержанием белка. Это голозерные сорта отечественной селекции Гатунок $(15,46 \%)$, Козацький $(15,16 \%)$, Ахіллес $(14,61 \%)$ и зарубежной Merlin $(15,23 \%)$, Alamo (14,93\%), Mebere (14,54\%), Millhouse (14,29\%), Голозерный 1 $(14,56 \%)$, Майский $(14,29 \%)$.

Установлено, что характерным есть более низкое содержание белка у шестирядных образцов в сравнении с двурядными во всех выделенных группах.

По показателю биологической ценности белка выделены сорта Парнас и Беркут $(69,80$ и 74,20 мг тирозина на 1 г белка соответственно). Сорт Парнас является возможным источником белка с высокой переваримостью. Это имеет значение для селекции сортов ячменя для производства продукции детского и диетического питания.

Ключевые слова: ячмень яровой, сорт, содержание белка, биологическая ценность, переваримость белка, голозерный ячмень

\section{CONTENT AND BIOLOGICAL VALUE OF PROTEIN IN GRAIN OF SPRING BARLEY ACCESSIONS}

${ }^{1}$ Vasko N.I., ${ }^{2}$ Serik M.L., ${ }^{1}$ Kozachenko M.R., ${ }^{1}$ Naumov O.G., ${ }^{1}$ Vazhenina O.E., ${ }^{1}$ Solonechnyi P.M., ${ }^{1}$ Solonechna O.V., ${ }^{1}$ Sheliakina T.A.

1 - Plant Production Institute nd. a. V.Ya. Yuriev of NAAS, Ukraine

2 - Kharkiv State University of Nutrition and Trade, Ukraine

The aim and tasks of the study. The study purpose was to identify genotypes with high protein content in grain as material for breeding to develop of food spring barley cultivars. To accomplish this, the protein content variability in different barley accessions - chaffy and naked ones, with wild type and waxy starch - was studied. To determine the protein value, its digestibility was determined.

Materials and methods. The study was conducted at the Plant Production Institute named after V.Ya. Yuriev of NAAS in 2015-2017. Seventy spring barley lines and cultivars of different eco-geographical origin were taken as the test material. The cultivars and lines were grown in variety trial plots with an area of $10 \mathrm{~m}^{2}$. Significance of differences between variants was tested by analysis of variance; post hoc comparisons to generate Homogeneous groups (Fisher LSD) were performed in the STATISTICA software package. The protein content in grain was measured on an Infralume FT-10M 09495. 
The protein digestibility was evaluated by O. Pokrovsky and I. Yertanov's method in the Laboratory of Medical and Biological Problems of Food Technology at the Chair of Chemistry, Microbiology and Nutrition of Kharkiv State University of Nutrition and Trade.

Results and discussion. It was established that in 2015-2017 the protein content in grain of spring barley accessions did not change significantly, depending on the growing conditions, and was mainly determined by genotype. The protein content was significantly higher $(12.05 \%-15.46 \%)$ in naked barley accession than in chaffy ones $(10.91 \%-13.82 \%)$. Of the chaffy cultivars, the protein content significantly exceeded the average throughout the experiment in Rezerv (13.82\%) only, while 11 of 16 naked cultivars under investigation had protein contents higher than the average throughout the experiment. In six-row barley, both in chaffy and naked accessions, the protein content was lower than that in two-row barley. Cultivars Parnas and Berkut were distinguished by protein digestibility, (69.80 and $74.20 \mathrm{mg}$ of tyrosine per gram of protein, respectively) as an indicator of biological value. Cultivar Berkut was created by selection from a hybrid population Parnas/Omskiy Golozyornyy-1, therefore Parnas is a possible source of protein with high digestibility, which is of interest for the breeding of barley cultivars to produce baby and dietic foods.

Conclusions. Thus, the three-year study resulted in identification of accessions with consistently high protein content. These are domestically bred naked cultivars Hatunok (15.46\%), Kozatskyi (15.16\%), Akhilles (14.61\%) and foreign cultivars Merlin (15.23\%), Alamo (14.93\%), Mebere (14, 54\%), Millhouse (14.29\%), Golozyornyy 1 (14.56\%), and Mayskiy (14.29\%).

It was found that a lower protein content was intrinsic to six-row accessions in comparison with two-row ones in all the studied groups.

Cultivars Parnas and Berkut (69.80 and $74.20 \mathrm{mg}$ of tyrosine per gram of protein, respectively) were distinguished by biological value of protein. Parnas is a possible source of protein with high digestibility. This is important for the breeding of barley cultivars to produce baby and dietic foods.

Keywords: spring barley, cultivar, protein content, biological value, protein digestibility, naked barley

\section{УРОЖАЙНІСТЬ ТА СТАБІЛЬНІСТЬ МИРОНІВСЬКИХ СОРТІВ ЯЧМЕНЮ ОЗИМОГО}

Гудзенко В.М.

Миронівський інститут пшениці імені В.М. Ремесла НААН, Україна

У 2012/13-2016/17 рр. проведено порівняльне випробування сортів ячменю озимого Миронівського інституту пшениці імені В.М. Ремесла НААН різних років (1987-2017) реєстрації за врожайністю та стабільністю. Результати системної оцінки за низкою параметричних i непараметричних статистичних показників та AMMI i GGE biplot засвідчили, що внесені до Держреєстру в 2014-2017 рр. сорти Паладін Миронівський, Атлант Миронівський, МІП Ясон, МІП Оскар, МІП Гладіатор переважають створені на попередніх етапах селекційної роботи сорти як за продуктивним, так і адаптивним потенціалом. У той же час як статистичні показники, так і візуалізації AMMI i GGE biplot вказують, що виділені сорти різняться за реакцією на контрастні умови років досліджень, а відповідно до цього у виробничих умовах доповнюватимуть один одного за відповідного формування сортового складу.

(C) Гудзенко В.М. 2018.

ISSN 1026-9959. Селекція і насінництво. 2018. Випуск 113. 